Beata Stypułkowska ${ }^{1}$

Wyższy Instytut Teologiczny w Częstochowie

\title{
Biblijne przykłady ludzi wiary i modlitwy w zastosowaniu katechetycznym
}

\section{Wprowadzenie}

Na różnych etapach edukacyjnych uczeń jest zachęcany do tego, by w Piśmie Świętym szukał wzorów życia wiary i modlitwy. Tak dzieje się na pierwszym ${ }^{2}$, drugim ${ }^{3}$, trzecim ${ }^{4}$ i czwartym ${ }^{5}$ etapie edukacyjnym. Ponadto na czwartym etapie edukacyjnym uczeń ma poznać przykłady ludzi powołanych w Biblii, aby dzięki temu zastanawiać się nad własnym

1 Beata Stypułkowska, od roku 2000 wykładowca katechetyki w Wyższym Instytucie Teologicznym w Częstochowie. Praca doktorska pt. Teoretyczne i praktyczne założenia przygotowania katechetów do poprawnej interpretacji tekstów biblijnych z uwzględnieniem form samoksztatcenia kierowanego, napisana pod kierunkiem bpa dra hab. Antoniego Długosza, obroniona na Wydziale Teologicznym Papieskiej Akademii Teologicznej w Krakowie w grudniu 1998 roku.

2 Konferencja Episkopatu Polski, Podstawa programowa katechezy Kościoła Katolickiego w Polsce [dalej: PP], Kraków 2010, s. 31; Komisja Wychowania Katolickiego Konferencji Episkopatu Polski, Program nauczania religii rzymskokatolickiej w przedszkolach i szkołach [dalej: PN], Kraków 2010, s. 45-46.

$3 \quad$ PP, s. 41; PN, s. 74, 82-83, 86.

$4 \quad$ PP, s. 58; PN, s. 111-113, 132-133.

5 PP, s. 75-76; PN, s. 147, 178-179, 214. 
powołaniem ${ }^{6}$. W trakcie swojej edukacji szkolnej uczeń interpretuje też wybrane psalmy oraz wyjaśnia rozmaite rodzaje modlitwy na przykładzie psalmów (czwarty etap edukacyjny ${ }^{7}$ ).

Nauczanie religii powinno dostarczyć uczniom przykładów życia wiary. Takie przykłady najpierw znajdziemy w Piśmie Świętym. Zarówno w Starym, jak i w Nowym Testamencie możemy przeczytać o osobach, które spotkały Boga, co wpłynęło na całe ich życie. W kanonie biblijnym mamy wyraźne wykazy ludzi, wobec których objawiła się Mądrość, będących przykładem życia wiary. Dwa spisy znajdują się w Starym Testamencie: jeden w Księdze Mądrości ${ }^{8}$, drugi w Mądrości Syracha w tzw. pochwale ojców ${ }^{9}$. Trzeci spis - w Nowym Testamencie - zamieścił autor Listu do Hebrajczyków ${ }^{10}$.

W niniejszym artykule najpierw zostaną przedstawione wykazy osób, które autorzy biblijni podają jako przykłady wiary i modlitwy. Następnie zostanie dokonana analiza Podstawy programowej katechezy Kościoła Katolickiego w Polsce i Programu nauczania religii rzymskokatolickiej w przedszkolach i szkołach pod tym kątem. Na końcu zostaną podane propozycje dla lekcji religii w szkole i katechezy parafialnej.

\section{Biblijne wykazy ludzi wiary i modlitwy}

Wykazy ludzi będących przykładami wiary w Mdr 10, 1 - 11, 3; Syr 44, 1 - 50, 24 i Hbr 11 zostały określone przez komentatorów jako midrasze, czyli taki rodzaj refleksji, w której poszukuje się sensu biblijnych opisów, komentując je i poddając aktualizacji1". Midrasze to utwory, których celem jest zrozumienie tekstu biblijnego w taki sposób, żeby prze-

\footnotetext{
PP, s. 75; PN, s. 143, 163, 175, 192, 200.

PP, s. 76; PN, s. 148, 179.

Mdr 10,1-11, 3 .

Syr $44,1-50,21$.

Hbr 11.

Pismo Święte Starego i Nowego Testamentu. Najnowszy przekład zjęzyków oryginalnych $z$ komentarzem. Opracował Zespół Biblistów Polskich z inicjatywy Towarzystwa Świętego Pawła [dalej: BCz], Częstochowa 2008, s. 1441-1442.
} 
mówił on do ludzi współczesnych autorowi ${ }^{12}$. Midrasz zakłada, że tekst biblijny zawiera niewyczerpany zasób znaczeń, odpowiednich i adekwatnych do każdej kwestii i sytuacji ${ }^{13}$.

\subsection{Postacie wymienione w Księdze Mądrości}

Księga Mądrości została napisana w I wieku przed Chrystusem, w Egipcie w Aleksandrii, w języku greckim ${ }^{14}$. Autorem jest bez wątpliwości Żyd, znający wiarę i kulturę własnego narodu, którego księgi i historia służą mu jako punkt odniesienia ${ }^{15}$. Z treści księgi wynika, że była ona przeznaczona przede wszystkim dla Żydów, którzy żyli w diasporze egipskiej. Miała ona umacniać wiarę ludzi na przykładzie historii Izraela, którym Bóg opiekował się w wyjątkowy sposób ${ }^{16}$. Niektórzy egzegeci wskazują żydowskich studentów w Aleksandrii jako szczególnych adresatów Księgi Mądrości, stąd też w księdze można spotkać nie tylko naukę, w jaki sposób przeciwstawić się atakom na wiarę objawioną, lecz także w jaki sposób wcielać pozytywne elementy kultury pogańskiej do swojego życia ${ }^{17}$. Nie wyklucza się również jako adresatów księgi pogan, wśród których byli rozproszeni Żydzi ${ }^{18}$. W Biblii Jerozolimskiej Księga Mądrości została podzielona na trzy

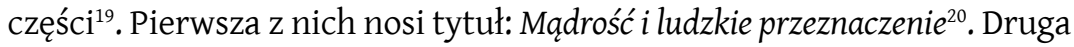
część została zatytułowana Salomon i poszukiwanie madrości ${ }^{21}$, trzecia nosi tytuł Mądrość działająca w historii² ${ }^{2}$.

12 J. S. Synowiec, Gatunki literackie w Starym Testamencie, Kraków 2003, s. 329.

13 Midrasz, [w:] Encyklopedia biblijna, red. P. J. Achtemeier, przekł. G. Berny, Warszawa 1999, s. 757.

14 S. Potocki, Rady mądrości. Przewodnik po mądrościowej literaturze Starego Testamentu, Lublin 1993, s. 261.

15 B. Poniży, Księga Mądrości. Wstęp - Przekład z oryginału - Komentarz, Częstochowa 2012, s. 32 .

16 B. Poniży, Księga Mądrości..., dz. cyt., s. 41.

17 B. Poniży, Księga Mądrości..., dz. cyt., s. 49.

18 B. Poniży, Księga Mądrości..., dz. cyt., s. 41.

19 O innych możliwych podziałach tej Księgi zob. B. Poniży, Księga Mądrości..., dz. cyt., s. 97-98.

20 Mdr 1-5.

21 Mdr 6-9.

22 Mdr 10-19. 
W trzeciej części w wersetach Mdr 10,1 - 11, 3 wymienione są osoby, które w katechezie mogą być przedstawiane jako przykłady ludzi wiary i modlitwy, którzy przyjaźnili się z Mądrością. Autor nie podaje ich imion, ale najczęściej nazywa Sprawiedliwymi. Są to w kolejności: Adam, określony jako Prarodzic ${ }^{23}$, Noe, Abraham, Lot, Jakub, Józef nazwani Sprawiedliwymi $^{24}$, Mojżesz nazwany Sługą Pańskim ${ }^{25}$ i Prorokiem ${ }^{26}$, lud wychodzący z Egiptu nazwany świętym ${ }^{27}$. Komentatorzy Biblii wydanej przez Towarzystwo św. Pawła zwracają uwagę, że autor Księgi Mądrości, wymieniając osoby przyjaźniące się z Mądrością, przekazuje duchowe przemyślenia nad wybranymi wydarzeniami z historii zbawienia, aby zachęcić czytelników do jeszcze większego zawierzenia Bogu i otwarcia się na dar mądrości ${ }^{28}$. Dalej komentatorzy podają, że jest to midrasz ${ }^{29}$.

Warto jeszcze w Księdze Mądrości zwrócić uwagę na Sprawiedliwego, który reprezentuje sprawiedliwych ${ }^{30}$, na którego bezbożni zamierzają uczynić zasadzkę ${ }^{31}$, ponieważ w tym tekście Kościół dostrzega proroctwo o Chrystusie. Tekst ten jest czytany w piątek w czwartym tygodniu Wielkiego Postu. Sprawiedliwy i Syn Boży w Nowym Testamencie często są synonimami Chrystusa ${ }^{32}$. Termin "Sprawiedliwy” w odniesieniu do Chrystusa zastosowano kilkakrotnie zarówno w ewangeliach synoptycznych, jak i w innych pismach Nowego Testamentu ${ }^{33}$.

Część druga Księgi Mądrości poświęcona jest królowi Salomonowi oraz jego poszukiwaniu Mądrości. Królowie byli uważani za ludzi, którzy winni odznaczać się mądrością, aby dzięki niej mogli podołać swoim zadaniom.

\footnotetext{
23 Mdr 10, 1 .

${ }^{24}$ Mdr 10, 4. 5. 6. 10. 13.

$25 \mathrm{Mdr} 10,16$.

26 Mdr 11, 1.

$27 \mathrm{Mdr} 10,17$.

$28 \quad \mathrm{BCZ}, \mathrm{s} .1441$.

29 BCz, s. 1441-1442.

30 B. Poniży, Sapiencjalne przejście od „przymierza” do „przyjaźni z Bogiem”, „Verbum Vitae" 4 (2003), s. 108-109.

31 Mdr 2, 12-22.

32 B. Poniży, Sprawiedliwy cierpiący. Echa Księgi Mądrości w ewangeliach synoptycznych, „Poznańskie Studia Teologiczne" 5 (1984), s. 106.

33 Mt 27, 19. 24; Łk 23, 47; Dz 3, 14; 7, 52; 22, 14; Rz 3, 12; 1 P 3, 18; $1 \mathrm{~J} \mathrm{2,} 1$.
} 
Salomon zyskał sobie sławę króla odznaczającego się szczególną mądroś$\mathrm{ciąa}^{34}, \mathrm{którą} \mathrm{osiągnął} \mathrm{dzięki} \mathrm{wierze} \mathrm{i} \mathrm{modlitwie} \mathrm{skierowanej} \mathrm{do} \mathrm{Boga.} \mathrm{Dlate-}$ go również Salomon może być dla katechizowanych przykładem człowieka wiary i modlitwy. Chodzi oczywiście o pierwszy etap jego życia. Z przekazu deuteronomistycznego dowiadujemy się o odstępstwie Salomona od Mądrości i jego bałwochwalstwie pod wpływem pogańskich żon ${ }^{35}$.

\subsection{Postacie wymienione w Mądrości Syracha}

Księga Syracha została napisana przez uczonego w Piśmie i jest przeznaczona dla ludzi wierzących, miłośników Prawa ${ }^{36}$. Księga ta znana jest też pod drugim tytułem: Eklezjasty. Można tę nazwę rozumieć jako księgę dla Kościoła szczególnie użyteczną, czytaną z pożytkiem dla pouczania i wychowywania wiernych ${ }^{37}$. Fragment Syr 44, 1- 50, 24 tworzy jednolitą całość. Autor sławi mądrość Boga przejawiającą się w życiu i działalności wybitnych mężów w historii Izraela ${ }^{38}$. Pochwała sławnych mężów stanowi oryginalną syntezę historii biblijnej ${ }^{39}$. Również ten fragment uważany jest przez egzegetów za midrasz ${ }^{40}$.

W Mądrości Syracha podano pochwałę władców, nauczycieli, proroków i mędrcó $w^{41} w$ kolejności ich pochodzenia, poczynając od Henocha ${ }^{42}$, a skończywszy na współczesnym autorowi arcykapłanie Szymonie II ${ }^{43}$.Zostali wymienieni w następującej kolejności: Henoch ${ }^{44}, \mathrm{Noe}^{45}, \mathrm{Abraham}^{46}$,

\footnotetext{
34 J. S. Synowiec, Mędrcy Izraela, ich pisma i nauka, Kraków 1997, s. 58.

$351 \mathrm{Krl} \mathrm{11,1-12.}$

36 S. Potocki, Rady mądrości, dz. cyt., s. 193.

37 S. Potocki, Księgimądrościowe, [w:] Wstęp do Starego Testamentu, red. S. Łach, PoznańWarszawa 1973, s. 722.

38 BCz, s. 1534.

39 W. Pazera, Pochwała ojców w Księdze Jezusa Syracha, „Częstochowskie Studia Teologiczne" 14 (1986), s. 271.

40 J. S. Synowiec, Gatunki literackie w Starym Testamencie, dz. cyt., s. 340.

41 Syr 44, 2-5.

42 Syr $44,16$.

43 Syr 50, 1-21.

44 Syr $44,16$.

${ }_{45}$ Syr 44, 17-18.

${ }^{46}$ Syr 44, 19-21.
} 
Izaak i Jakub ${ }^{47}$, Mojżesz $^{48}$, Aaron ${ }^{49}$, Pinchas $^{50}$, Jozue ${ }^{51}$, Kaleb $^{52}$, Sędziowie ${ }^{53}$, Samuel $^{54}$, Natan ${ }^{55}$, Dawid ${ }^{56}$, Salomon ${ }^{57}$, Roboam ${ }^{58}$, Jeroboam ${ }^{59}$, Eliasz ${ }^{60}$, Elizeusz $^{61}$, Ezechiasz ${ }^{62}$, Izajasz ${ }^{63}$, Jozjasz ${ }^{64}$, Ostatni królowie i ostatni proro$\mathrm{cy}^{65}$, Zorobabel i Jozue ${ }^{66}$, Nehemiasz ${ }^{67}$, Kapłan Szymon ${ }^{68}$. W streszczeniu powtórzono imiona Henocha, dodano Józefa, Sema i Seta oraz Adama ${ }^{69}$.

Charakterystyka każdej postaci ma charakter komentarza mądrościowego, w którym Syrach podkreśla wkład opisywanych postaci w rozwój historii zbawienia ${ }^{70}$. Zgodnie z zasadami midraszów autor wykorzystuje w nim treści zaczerpnięte z wcześniejszych ksiąg biblijnych i w oparciu o nie przedstawia czytelnikom swoje rozumienie dziejów Izraela, daleko bardziej optymistyczne niż w Pięcioksięgu i dziele deuteronomistycznym. $\mathrm{Z}$ wielkim uznaniem mówi o dziełach wielkich proroków ${ }^{71}$. Jest natomiast bardzo krytyczny wobec królów izraelskich i judzkich ${ }^{72}$ z wyjątkiem Da-

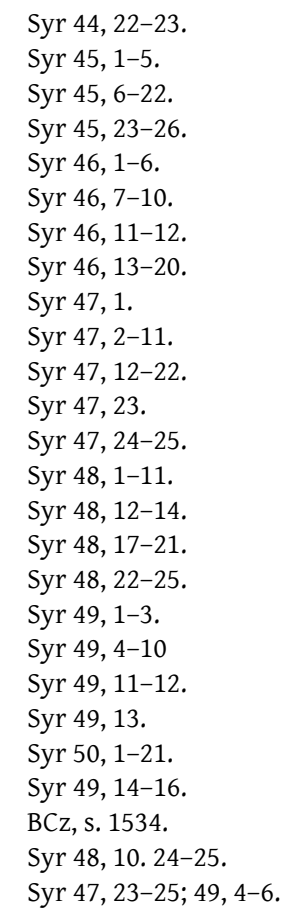


wida, Salomona, Ezechiela i Jozjasza ${ }^{73}$. Najwięcej pochwał wyraża wobec Aarona $^{74}$ i arcykapłana Szymona ${ }^{75}$.

Nie wszystkim wymienionym przez siebie postaciom Syrach poświęcił uwagę w tym samym stopniu. Osnowę całej pochwały stanowi wykaz dwudziestu czterech ojców, których zasługi Syrach opisuje w sposób szczegółowy i dokładny. Są to: Henoch, Noe, Abraham, Izaak, Jakub, Mojżesz, Aaron, Pinchas, Jozue, Kaleb, Samuel, Dawid, Eliasz, Elizeusz, Ezechiasz, Izajasz, Jozjasz, Jeremiasz, Ezechiel, Hiob, Zorobabel, Jozue, Nehemiasz i arcykapłan Szymon. Ponadto dokładnie opisuje Roboama i Jeroboama, ale ocenia ich negatywnie. Następnie siedem osób Syrach wymienia imiennie, nie zachowując chronologii oraz nie wspomina o ich dokonaniach. Są to: Eleazar, Natan, Józef Egipski, Sem, Set, Enosz i Adam. Ogólną liczbę sławnych ojców należy poszerzyć o dwunastu proroków mniejszych, o których Syrach pisze, że „podtrzymywali nadzieję w Izraelu" (Syr 49, 10). Łącznie zatem mamy wykaz czterdziestu pięciu najbardziej znanych postaci w historii Izraela, przez których działała mądrość Boża ${ }^{76}$.

\subsection{Postacie wymienione w Liście do Hebrajczyków}

List do Hebrajczyków skierowany jest do nawróconych Żydów, może nawet dawnych kapłanów, których autor stara się umocnić w wierze i uchronić przed powrotem do praktyk judaistycznych. Inni sądzą, że adresatami listu są dawni poganie, którzy przyjęli wiarę w Chrystusa. List zwraca się do wspólnoty chrześcijańskiej złożonej pewnie z dawnych hellenistów i „hebrajczyków”77. Niektórzy egzegeci cały List do Hebrajczyków uważają za homiletyczny midrasz, oparty na Psalmie $110^{78}$. Dlatego za midrasz możemy uważać również rozdział 11 tego listu. Podobnie jak w Mdr 10,1 - 11, 3 i Syr 44,1 - 50, 24 dostrzegamy tutaj szukanie

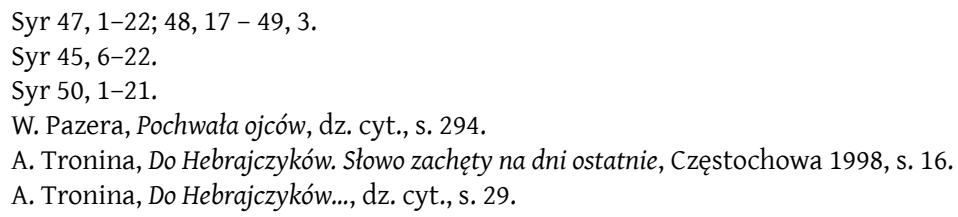


w tekstach biblijnych Starego Testamentu ich głębszej treści, aktualnej dla współczesnych ${ }^{79}$, w tym przypadku dla chrześcijan, którzy Stary Testament uznają za swoje dziedzictwo.

Autor Listu do Hebrajczyków w 11 rozdziale wymienia szereg imion osób z historii zbawienia, stawiając je jako przykład wiary dla chrześcijan. Autor chce wyjaśnić, że dzieje człowieka z Bogiem są dziejami wia$\mathrm{ry}^{80}$. Listę rozpoczyna Abel ${ }^{81}$, następnie wymienieni są Henoch ${ }^{82}, \mathrm{Noe}^{83}$, Abraham $^{84}$, Sara $^{85}$, Izaak i Jakub ${ }^{86}$, Józef ${ }^{87}$, rodzice Mojżesza ${ }^{88}$, Mojżesz ${ }^{89}$, zdobywcy Ziemi Obiecanej ${ }^{90}$ i Rachab ${ }^{91}$. Autor podaje jeszcze imiona Gedeona, Baraka, Samsona, Jeftego, Dawida, Samuela i mówi ogólnie o Prorokach $^{92}$. Katalog wieńczy Jezus, „który jest początkiem i celem naszej wiary" ${ }^{93}$.Jak widać, imiona z historii zbawienia podane są egzemplarycznie, bez zachowania chronologii, i mają znaczenie ogólnych wzorców ${ }^{94}$. Można bowiem w historii biblijnej doszukać się jeszcze wielu postaci, których wiara mogłaby być stawiana za wzór współczesnym chrześcijanom. Autor Listu do Hebrajczyków, przemierzając historię zbawienia, dostrzega w postawie osób ze Starego Testamentu zapowiedź tajemnicy Chrystusa. Wiara pozwala człowiekowi żyć w osobistej łączności z Bogiem, otwierać się na przyszłość obiecaną przez Niego i na zwycięstwo nad śmiercią dzięki zmartwychwstaniu Chrystusa ${ }^{95}$.

\footnotetext{
79 A. Tronina, Do Hebrajczyków..., dz. cyt., s. 30.

80 Pismo Święte Starego i Nowego Testamentu w przekładzie zjęzyków oryginalnych. List do Hebrajczyków, tłum., wstęp i komentarz ks. A. Paciorek, Lublin 1998, s. 124.

81 Hbr 11, 4.

$82 \operatorname{Hbr} 11,5$.

83 Hbr 11, 7.

84 Hbr 11, 8-19.

85 Hbr 11, 11-12.

86 Hbr 11, 9. 20-21.

87 Hbr 11, 22.

88 Hbr 11, 23.

89 Hbr 11, 24-28.

90 Hbr 11, 29-30.

91 Hbr 11, 31.

92 Hbr 11, 32-40.

$93 \mathrm{Hbr} 12,2$.

94 A. Tronina, Do Hebrajczyków..., dz. cyt., s. 150.

${ }_{95}$ BCz, s. 2636-2637.
} 
Wprawdzie nie znamy autora Listu do Hebrajczyków, ale jesteśmy pewni, że list ten jest natchnionym słowem Bożym. Uczeń powinien dowiedzieć się, że kwestie dotyczące autorstwa i czasu powstania wcale nie są tożsame z pytaniem o natchnienie i tym samym nie wykluczają tego listu z kanonu Pisma Świętego ${ }^{96}$.

\subsection{Osoby powtarzające się w biblijnych wykazach}

W biblijnych wykazach trzy razy występuje Noe $^{97}$, Abraham ${ }^{98}$, Jakub ${ }^{99}$, Józef ${ }^{100}$ i Mojżesz ${ }^{101}$. Dwa razy wymieniono Adama ${ }^{102}$, Henocha ${ }^{103}$, Izaaka ${ }^{104}$, lud wychodzący z Egiptu i zdobywający Ziemię Obiecaną $a^{105}$, Samuela ${ }^{106} \mathrm{i}$ Dawida ${ }^{107}$. Raz wymieniono Sema ${ }^{108}$, Seta ${ }^{109}$, Lota ${ }^{110}$, rodziców Mojżesza ${ }^{111}$, Aarona $^{112}$, Pinchasa ${ }^{113}$, Jozuego ${ }^{114}$, Kaleba ${ }^{115}$, Rachab ${ }^{116}$, Gedeona ${ }^{117}$, Baraka ${ }^{118}$,

96 A. Läpple, Od egzegezy do katechezy. Nowy Testament, przeł. B. Białecki, Warszawa 1986, s. 180.

${ }_{97}$ Mdr 10, 4; Syr 44, 17-18; Hbr 11, 7.

${ }_{98}$ Mdr 10, 5; Syr 44, 19-21; Hbr 11, 8-19.

Mdr 10, 13; Syr 49, 15; Hbr 11, 22.

Mdr 10, 16; 11, 1; Syr 45, 1-5; Hbr 11, 24-28.

Mdr 10, 1; Syr 49, 16.

Syr 44, 16; Hbr 11, 5.

Syr 44, 22-23; Hbr 11, 9. 20.

Mdr 10, 17; Hbr 11, 29-30.

Syr 46, 13-20; Hbr 11, 32.

Syr 47, 2-11; Hbr 11, 32.

Syr 49, 16.

Syr $49,16$.

Mdr 10, 6.

Hbr 11, 23.

Syr 45, 6-22.

Syr 45, 23-26.

Syr 46, 1-6.

Syr 46, 7-10.

Hbr 11, 31 .

Hbr 11, 32.

Hbr 11, 32. 
Samsona ${ }^{119}$, Jeftego ${ }^{120}$, Salomona ${ }^{121}$, Roboama ${ }^{122}$, Jeroboama ${ }^{123}$, Eliasza ${ }^{124}$, Elizeusza $^{125}$, Ezechiasza ${ }^{126}$, Izajasza ${ }^{127}$, Jozjasza ${ }^{128}$, Zorobabela i Jozuego ${ }^{129}$, Nehemiasza $^{130}$, kapłana Szymona ${ }^{131}$. Wszystkie osoby wymieniane przez autorów biblijnych warte są chociażby wzmianki w czasie lekcji religii i katechezy parafialnej, należą bowiem do osób, które tworzyły historię zbawienia.

\section{Elementy biblijne dotyczące przykładów wiary w Podstawie programowej katechezy Kościoła Katolickiego w Polsce oraz w Programie nauczania religii rzymskokatolickiej w przedszkolach i szkołach}

Podstawa programowa katechezy Kościoła Katolickiego w Polsce przedstawia treści katechezy według zadań katechezy sformułowanych przez dyrektoria katechetyczne ${ }^{132}$. Dodatkowo podaje zadania nauczyciela religii. Elementy biblijne są rozproszone wśród różnych zadann ${ }^{133}$. Interesu-

\footnotetext{
119 Hbr 11, 32.

120 Hbr 11, 32.

121 Syr 47, 12-22.

122 Syr 47, 23.

123 Syr 47, 24-25.

124 Syr 48, 1-11.

125 Syr 48, 12-14.

126 Syr 48, 17-21.

127 Syr 48, 22-25.

128 Syr 49, 1-3.

129 Syr 49, 11-12.

130 Syr 49, 13.

131 Syr 50, 1-21.
}

132 Wymienionych jest sześć podstawowych zadań katechezy: rozwijanie poznania wiary, wychowanie liturgiczne, formacja moralna, nauczanie modlitwy, wychowanie do życia wspólnotowego i wprowadzenie do misji - Kongregacja ds. Duchowieństwa, Dyrektorium ogólne o katechizacji [dalej: DOK], Poznań 1998, nr. 85-86; Konferencja Episkopatu Polski, Dyrektorium katechetyczne Kościoła katolickiego w Polsce [dalej: PDK], Kraków 2001, nr 23-29.

133 Przy rozwijaniu poznania wiary elementy biblijne występują na wszystkich etapach edukacyjnych (PP, s. 29, 40, 53 i 73); przy wychowaniu liturgicznym elementy biblijne występują na drugim (PP, s. 40) i trzecim etapie edukacyjnym (PP, s. 54), przy formacji moralnej elementy biblijne występują na wszystkich etapach edukacyjnych (PP, s. 30, 41, 55 i 75); przy wychowaniu do modlitwy elementy biblijne występują na wszystkich etapach eduka- 
jące nas treści programowe znajdują się w kontekście formacji moralnej (pierwszy etap edukacyjny: klasy I-III szkoły podstawowej oraz czwarty etap edukacyjny: szkoły ponadgimnazjalne), wychowania do modlitwy (pierwszy etap edukacyjny: klasy I-III szkoły podstawowej, drugi etap edukacyjny: klasy IV-VI szkoły podstawowej oraz czwarty etap edukacyjny: szkoły ponadgimnazjalne) i rozwijania poznania wiary (trzeci etap edukacyjny: gimnazjum). W dyrektoriach katechetycznych zadanie rozwijania poznania wiary umieszczone jest na pierwszym miejscu. Dyrektorium ogólne o katechizacji wskazuje: „Pogłębienie w poznaniu wiary oświeca po chrześcijańsku życie ludzkie, umacnia życie wiary oraz uzdalnia do uzasadnienia jej w świecie. Przekazanie Symbolu wiary, streszczenia Pisma Świętego i wiary Kościoła wyraża realizację tego zadania" ${ }^{134}$.W dokumencie tym mowa jest o streszczeniu Pisma Świętego bez podania bliższych wskazówek. W Dyrektorium katechetycznym Kościoła Katolickiego w Polsce podano ogólnie, że zadanie rozwijania poznania wiary dokonuje się przez poznanie Tradycji i Pisma Świętego ${ }^{135}$. Formacja moralna zakłada według Dyrektorium ogólnego o katechizacji zapoznanie ucznia przede wszystkim z Kazaniem na górze, „, w którym Jezus podejmuje na nowo dekalog i wyciska na nim ducha błogosławieństwa" ${ }^{136}$. Podstawa programowa i Program katechetyczny rozszerzają znaczenie tego zapisu przez zaproponowanie biblijnych przykładów wiary.

Na pierwszym etapie edukacyjnym w Podstawie programowej przy formacji moralnej wśród wiadomości znajdujemy zapis: postaci biblijne

cyjnych (PP, 31, 41, 56 i 76); przy wychowaniu do życia wspólnotowego elementy biblijne występują na trzecim (PP, 56) i czwartym etapie edukacyjnym (PP, s. 76); przy wprowadzeniu do misji elementy biblijne występują na pierwszym (PP, s. 32) i trzecim etapie edukacyjnym (PP, s. 58). W odniesieniu do problematyki biblijnej w polskich dokumentach katechetycznych warto zapoznać się z uwagami biblisty ks. dr. hab. Wojciecha Pikora. Autor wprawdzie odnosi się do Podstawy programowej i Programu nauczania z roku 2001, ale wiele uwag jest aktualnych także wobec obecnie obowiązujących dokumentów - W. Pikor, Hermeneutyka biblijna w katechezie. Interpretacja Pisma Świętego w świetle polskich dokumentów katechetycznych, „Katecheta” 51 (2007) nr 5, s. 3-11.

134 DOK, nr 85.

135 PDK, nr 24. Polski dokument katechetyczny powołuje się w tym miejscu na DOK, nr 85 i $95-96$.

136 PDK, nr 24. 
przykładem życia wiary oraz przykłady życia według Ewangelii. Uczeń natomiast ma wskazać, w czym może naśladować postaci biblijne ${ }^{137}$. W Podstawie nie wymieniono jednak w tym miejscu żadnych konkretnych imion. W Programie nauczania religii rzymskokatolickiej w przedszkolach i szkołach na tym etapie w klasie pierwszej szkoły podstawowej zaproponowano przedstawienie Świętej Rodziny jako przykładu życia dla naszych rodzin $^{138}$. W klasie drugiej program proponuje poznanie wybranych osób biblijnych słuchających słów Boga ${ }^{139}$. Wymienieni są: Adam i Ewa, Abraham, Mojżesz, Samuel i Maryja ${ }^{140}$. Następnie w Podstawie programowej na tym etapie przy zadaniu wychowania do modlitwy wymieniono Jezusa i Maryję jako wzory modlitwy ${ }^{141}$. W Programie nauczania to zagadnienie podjęto jedynie w klasie trzeciej szkoły podstawowej, w treściach podając przykłady modlitwy w Piśmie Świętym ${ }^{142}$. Można przypuszczać, że zapoznając uczniów z życiem publicznym Jezusa oraz omawiając tematykę maryjną, katecheta podejmie również temat modlitwy Jezusa i modlitwy Maryi.

Na drugim etapie edukacyjnym w Podstawie programowej przy zadaniu wychowania do modlitwy wśród wiadomości znajdujemy zapis o różnych sposobach i rodzajach modlitwy w oparciu o przykłady biblijne ${ }^{143}$. W treściach - wymaganiach szczegółowych wśród wiadomości ucznia wymieniono przykłady ludzi modlitwy ${ }^{144}$. W Programie nauczania w klasie piątej szkoły podstawowej sformułowano jako cel katechetyczny motywowanie na przykładzie bohaterów biblijnych do umacniania własnej relacji z Bogiem ${ }^{145}$, a w wymaganiach podano, że uczeń ocenia własne postępowanie w świetle wybranych przykładów bohaterów biblijnych ${ }^{146}$. Wśród bohaterów biblijnych wymieniono Abrahama,Jakuba, Józefa i Moj-

\footnotetext{
137 PP, s. 31.

138 PP, s. 37.

139 PP, S. 45.

140 PP, s. 46.

141 PP, s. 31.

142 PN, S. 53.

143 PP, S. 41.

144 PP.

145 PN, s. 82.

146 PN, s. 83.
} 
żesza ${ }^{147}$. W klasie szóstej w celach katechetycznych podano zapoznanie się z życiem i działalnością św. Piotra i św. Pawła ${ }^{148}$, a wśród treści podano, że życie pierwszych wspólnot chrześcijańskich powinno być przedstawione jako wzór dla dzisiejszego Kościoła ${ }^{149}$.

Na trzecim etapie edukacyjnym w Podstawie programowej przy zadaniu rozwijania poznania wiary wśród zadań nauczyciela religii znajdujemy zapis o wprowadzeniu w historię zbawienia ${ }^{150}$.W treściach - wymaganiach szczegółowych wśród wiadomości ucznia wymieniono główne wydarzenia i postaci starotestamentowej historii zbawienia ${ }^{151}$. Szczegółowo rozpisano cele, jakie osiągnie uczeń. Wśród celów znajdują się: uczeń przedstawia podstawowe wydarzenia należące do starotestamentowej historii zbawienia w porządku chronologicznym (patriarchowie, wędrówka do Ziemi Obiecanej, epoka Sędziów, pierwsi królowie, podzielone królestwo, niewola babilońska, powstanie machabejskie, sytuacja Izraela przed narodzeniem Chrystusa); prezentuje najważniejsze wydarzenia z życia wybranych postaci starotestamentowych: patriarchów, Mojżesza, Jozuego, Samuela, Saula, Dawida, Salomona, Braci Machabejskich, wybranych proroków. Uczeń powinien dokonywać aktualizacji faktów związanych z wybranymi postaciami Starego i Nowego Testamentu ${ }^{152}$. Przy zadaniu ,wprowadzenie do misji" wśród wiadomości podano zapis o biblijnych przykładach świadków wiary ${ }^{153}$. Uczeń ma wyjaśnić, jak można naśladować postacie biblijne $\mathrm{w}$ wyznawaniu wiary ${ }^{154}$. W Programie nauczania w klasie pierwszej gimnazjum zalecono poznanie Jozuego, Sędziów, Samuela, Saula, Dawida, Salomona, Eliasza, Izajasza, Jeremiasza, Braci Machabejskich ${ }^{155}$. W klasie trzeciej gimnazjum podano biblijne przykłady powołań: Samuela, Izajasza, Jeremiasza, św. Andrzeja, św. Piotra, św. Mateusza i św. Pawła ${ }^{156}$.

$\begin{array}{ll}147 & \text { PN, s. 82. } \\ 148 & \text { PN, s. 93. } \\ 149 & \text { PN. } \\ 150 & \text { PP, s. 53. } \\ 151 & \text { PP. } \\ 152 & \text { PP. } \\ 153 & \text { PP, s. 58. } \\ 154 & \text { PP. } \\ 155 & \text { PN, s. 112-113. } \\ 156 & \text { PN, s. 131. }\end{array}$


Na czwartym etapie edukacyjnym w Podstawie programowej przy zadaniu formacji moralnej w wiadomościach znajdujemy zapis o biblijnych przykładach osób powołanych ${ }^{157}$, a przy zadaniu wychowania do modlitwy jest zapis o biblijnych wzorcach modlitwy ${ }^{158}$. W Programie nauczania w klasie pierwszej liceum, technikum i szkoły zawodowej znajdujemy w treściach zapis o biblijnych wzorcach modlitwy ${ }^{159}$, a według wymagań uczeń ma scharakteryzować postaci biblijne, przedstawiając je jako wzory modlitwy dla chrześcijanina ${ }^{160}$. W klasie trzeciej liceum i klasie czwartej technikum wśród treści znajdują się osoby powołane w Bibliii ${ }^{161}$. Program wymienia jedynie Maryję jako pierwszą powołaną ${ }^{162}$. W klasie drugiej szkoły zawodowej w treściach nie ma mowy o osobach powołanych w Biblii, ale jest mowa o Maryi jako pierwszej powołanej ${ }^{163}$.

Niektóre postaci biblijne podawane są wprost jako wzorce ludzi wiary. Gdy mowa o biblijnych przykładach ludzi modlitwy i osobach powołanych w Biblii, przykłady te pośrednio dotyczą również postaw wiary. Ludzie modlitwy są bowiem ludźmi wiary, podobnie jak osoby odpowiadające pozytywnie na powołanie od Boga.

\section{Propozycje katechetyczne odnoszące się do przedstawiania przykładów ludzi wiary i modlitwy}

Przykłady ludzi wiary i modlitwy podane przez Księgę Mądrości, Mądrość Syracha i List do Hebrajczyków odnoszą się do osób starotestamentowych. Aby zapoznać się dokładniej z wymienionymi osobami, uczeń będzie korzystał z wielu tekstów w różnych księgach biblijnych. Pomocne jest też spojrzenie autora nowotestamentowego na historię ludzi wiary. Przybliżanie tych postaci na lekcjach religii i w katechezie parafialnej

\footnotetext{
157 PP, s. 75.

158 PP, s. 76.

159 PN, s. 147, 178, 214.

160 PN, S. 148, 179, 214.

161 PN, s. 163, 200.

162 PN, s. 163, 200.

163 PN, s. 218.
} 
wspomoże poznanie przez uczniów historii biblijnej oraz zwróci uwagę na kanon Pisma Świętego, którego poznawanie jest pożyteczne i potrzebne w dążeniu do dojrzałości chrześcijańskiej.

\subsection{Lekcja religii}

W odniesieniu do lekcji religii warto zwrócić uwagę na osoby podane w Podstawie programowej i Programie nauczania. Ich ukazanie może być egzemplaryczne, bez odwoływania się do pełnych wykazów zawartych w Księdze Mądrości, Mądrości Syracha i Liście do Hebrajczyków. Treści katechetyczne mogą być też czerpane bezpośrednio z Pięcioksięgu lub ksiąg historycznych. Nauka zawarta w księgach mądrościowych i Liście do Hebrajczyków może wzbogacić przekaz katechetyczny, ale nie jest konieczne zapoznawanie uczniów z tymi tekstami.

\subsection{Katecheza w parafii}

W odniesieniu do katechezy parafialnej nie ma wypracowanej podstawy programowej ani programu nauczania. Dlatego podane tu sugestie katechetyczne do realizacji w różnych grupach parafialnych, ze szczególnym uwzględnieniem grupy biblijnej i formacji lektorów i psałterzystów, można potraktować jako propozycje. Propozycje te dotyczą katechezy stałej, skierowanej do uczestników, którzy przeszli etap katechezy wtajemniczającej i oczekują pogłębionej formacji katechetycznej, zmierzającej ku dojrzałości w wierze.

\subsubsection{Grupa biblijna}

W ramach grupy biblijnej można podjąć studium tematyczne Pisma Świętego. Studium tematyczne jest drugim obok kursorycznego podstawowym rodzajem czytania Pisma Świętego. Należy wybrać określone zagadnienie i systematycznie przeczytać wszystkie fragmenty w Biblii, które się do niego odnoszą. Przy tym rodzaju studium pomocne są słowniki biblijne i konkordancje. Postacie biblijne podawane jako przykłady ludzi wiary i modlitwy mogą być wdzięcznym przedmiotem studium biblijnego. 
Tematyczna lektura Biblii ułatwia wypracowanie syntezy biblijnej dotyczącej określonego zagadnienia. Tym zagadnieniem mogą być biblijne przykłady ludzi wiary i modlitwy. Uczestnicy kręgu mogą po kolei poznawać poszczególne spisy ludzi wiary i modlitwy. Przy poznawaniu określonej osoby czytający najpierw sami wyszukują wszystkie teksty biblijne odnoszące się do nich, biorąc pod uwagę wszystkie księgi biblijne. Mogą to robić przy pomocy konkordancji i słowników albo idąc za wskazówkami katechety. Następnie należy zgrupować poszczególne teksty, wybierając kryterium treściowe (zwracając uwagę przede wszystkim na podobieństwa i różnice biblijnych wypowiedzi), kryterium chronologiczne (biorąc pod uwagę czas powstania danej wypowiedzi) lub rodzajowe (przyporządkowując daną wypowiedź do określonej grupy tekstów ze względu na jej rodzaj i gatunek literacki). Z zebranych fragmentów tworzy się syntezę, nie zaniedbując zapisywania parametrów biblijnych, tak by w każdej chwili można było odszukać dany tekst.

\subsubsection{Formacja służby liturgicznej}

Formacja podstawowa służby liturgicznej powinna odbywać się według opracowanego programu rozłożonego na cztery etapy w odniesieniu do dzieci i młodzieży ${ }^{164}$ orazjeden etap, po okresie wprowadzającym, w odniesieniu do dorosłych ${ }^{165}$.

Formacja stała natomiast nie jest bliżej określona. Dotyczyć będzie ona głównie osób dorosłych. Dokumenty katechetyczne nie wspominają o katechezie dorosłych posługujących w liturgii. Dyrektorium katechetyczne Kościoła katolickiego w Polsce o zespołach liturgicznych mówi tylko w odniesieniu do dzieci i młodzieży, nie odnosząc ich do katechezy dorosłych ${ }^{166}$. Jednakże II Polski Synod Plenarny w odniesieniu do pa-

164 Konferencja Episkopatu Polski, Dyrektorium duszpasterstwa służby liturgicznej [dalej: DDSL], Warszawa 2009, nr 60-99.

165 DDL, nr 101-106.

166 PDK, nr 110. Nie brak natomiast pozycji o związku katechezy dorosłych z liturgią, zob. W. Nowak, Katecheza dorosłych i liturgia, [w:] Katecheza dorosłych w teorii i praktyce. Impulsy-wyzwania-perspektywy, red. C. Rogowski, Lublin-Olsztyn 2001, s. 137-157. W podanym artykule mowa jest o przygotowaniu dorosłych dp celebrowania misterium Chrystusa w li- 
rafii zaleca zespoły liturgiczne, które są złożone z dorosłych, młodzieży i dzieci ${ }^{167}$. Podobnie wypowiada się Dyrektorium duszpasterstwa służby liturgicznej ${ }^{168}$. Dorośli mogą włączyć się we wspólnotę lektorów, psałterzystów, akolitów, przynoszących dary i zbierających składkę lub śpiewających w chórze ${ }^{169}$. Innymi funkcjami liturgicznymi, które mogą podjąć dorośli, są następujące posługi: nadzwyczajnych szafarzy Komunii Świętej, animatorów liturgicznych, ceremoniarzy, organistów, kantorów i dyrygentów chóru, zakrystian ${ }^{170}$. Główny ciężar formacji służby liturgicznej spoczywa na parafii ${ }^{171}$. W miarę rozwoju grup liturgicznych tworzy się w parafii liczna wspólnota osób, do której należą dorośli, którzy coraz bardziej wytrwale chcą dążyć do świętości ${ }^{172}$.

W formacji biblijnej osób posługujących podczas liturgii słowa, głównie dorosłych lektorów i psałterzystów, należy przyjąć klucz liturgiczny, tzn. należy omawiać te fragmenty, które aktualnie czytane są podczas liturgii słowa zarówno w cyklu niedzielnym, jak i w cyklu dni powszednich ${ }^{173}$.

turgii, bez wskazania możliwości podjęcia w czasie liturgii różnych posług, które mogą spełniać świeccy.

167 II Polski Synod Plenarny (1991-1999). Liturgia Kościoła po Soborze Watykańskim II, Poznań 2001, n. 83.

168 DDSL, nr 3, 54, 100-146.

169 DDSL, nr 105. Mężczyźni mogą być ustanowieni na stałe akolitami lub lektorami. Ich formacja przeprowadzana jest w diecezji - DDSL, nr 109.

170 DDSL, nr 131-146. Nadzwyczajni szafarze Komunii Świętej, animatorzy liturgiczni, ceremoniarze, organiści również w diecezji otrzymują podstawową formację do wykonywania swojej posługi.

171 DDSL, nr 164.

172 DDSL, nr 167.

173 W okresie zwykłym czytane są wówczas księgi historyczne, dydaktyczne i prorockie (bez Księgi Izajasza). W Adwencie i w okresie Bożego Narodzenia czytane są: Księga Izajasza, po uroczystości Objawienia Pańskiego Listy św. Pawła, ukazujące misterium chrześcijańskie. W czasie Wielkiego Postu czytany jest Pięcioksiąg, a w ostatnim Wielkim Tygodniu Księga Jeremiasza i pieśni Sługi Jahwe z drugiej części Księgi Izajasza, które są wprowadzeniem do opisów męki Pańskiej w Ewangeliach i ich komentarza w Liście do Hebrajczyków. Na okres wielkanocny przeznacza się lekturę Dziejów Apostolskich, Listów Pasterskich i pism św. Jana. Ewangelie powinny być czytane nieustannie, równolegle z innymi księgami, w Wielkim Poście zwłaszcza wskazana jest lektura Ewangelii według św. Jana - L. Bouyer, Wprowadzenie do życia duchowego. Zarys teologii ascetycznej i mistycznej, przeł. L. Rutowska, Warszawa 1982, s. 40. W niedziele obowiązuje trzyletni cykl czytań. W każdym roku czytana jest jedna Ewangelia w sposób ciągły. W roku A - Ewangelia według św. Mateusza, w roku B - Ewangelia według 
Fragmenty z Księgi Mądrości czytane są podczas liturgii słowa, ale niestety nie ma w nich wykazu osób przyjaźniących się z Mądrością z wersetów Mdr 10, 1 - 11, 3. Gdy chodzi o Mądrość Syracha, to w 8 tygodniu okresu zwykłego w piątek w roku I czytany jest fragment pochwały wielkich przodków (Syr 44, 1. 9-13). W 11 tygodniu okresu zwykłego w czwartek w roku II czytana jest pochwała Eliasza i Elizeusza (Syr 48,1-14). W 4 tygodniu okresu zwykłego w piątek w roku II czytana jest pochwała Dawida (Syr 47, 2-11).

W odniesieniu do Listu do Hebrajczyków w 3 tygodniu okresu zwykłego w sobotę w roku I czytana jest perykopa: Wiara Abrahama wzorem dla nas (Hbr 11, 1-2. 8-19). W 6 tygodniu okresu zwykłego w sobotę w roku I czytana jest perykopa zatytułowana Wiara patriarchów (Hbr 11, 1-7). W 19 tygodniu okresu zwykłego w niedzielę w roku C czytana jest perykopa zatytułowana Wielkość wiary (Hbr 11, 1-2. 8-19). W 20 tygodniu okresu zwykłego w niedzielę w roku C czytana jest perykopa zatytułowana Przykład Chrystusa (Hbr 12,1-4).

\subsection{Studium indywidualne ucznia}

Zarówno podczas lekcji religii, jak i katechezy parafialnej, uczeń winien być zachęcany i wdrażany do podjęcia indywidualnej lektury Pisma

św. Marka; w roku C - Ewangelia według św. Łukasza. Perykopy z Ewangelii według św. Jana występują częściowo w cyklu B oraz przewidziane są na okres Wielkiego Postu i Wielkanocy. W czasie liturgii niedzielnej pierwsze czytanie pochodzi zazwyczaj ze Starego Testamentu (z wyjątkiem okresu wielkanocnego, kiedy czytane są Dzieje Apostolskie) i wiąże się tematycznie z Ewangelią. Drugie czytanie pochodzi z Nowego Testamentu (z listów) i również, tak jak Ewangelia, ma charakter ciągły. Gdy rozważamy zatem tekst Ewangelii niedzielnej, jej powiązań tematycznych winniśmy szukać przede wszystkim w pierwszym czytaniu. Również psalm responsoryjny związany jest tematycznie z pierwszym czytaniem. Stanowi on odpowiedź wspólnoty na usłyszane słowo Boże. W dzień powszedni obowiązuje dwuletni cykl czytań (rok I i II). Przed Ewangelią jest tylko jedno czytanie i psalm responsoryjny. Czytania są zarówno ze Starego, jak i Nowego Testamentu. Mają one charakter ciągły, podobnie jak perykopy z Ewangelii. Rok I od roku II różni się tylko pierwszym czytaniem i psalmem responsoryjnym, aklamacja przed Ewangelią i sama Ewangelia jest w każdym roku w dniu powszednim taka sama. Okresy Adwentu, Bożego Narodzenia, Wielkiego Postu i Wielkiej Nocy mają własne czytania, powtarzane co roku. Dostrzegamy zatem pewną cykliczność czytań. W ciągu roku można poznać wszystkie fragmenty Ewangelii przeznaczone dla liturgii mszalnej w dni powszednie, w ciągu dwóch lat pierwsze czytania i psalmy z dni powszednich, a w ciągu trzech lat czytania przeznaczone na niedziele. 
Świętego ${ }^{174}$. Niekiedy uczeń podejmuje taką lekturę, przygotowując się pod kierunkiem nauczyciela religii do konkursów biblijnych. Indywidualna lektura Pisma Świętego może się odbywać w formie studium kursorycznego lub tematycznego. Ponieważ studium tematyczne było wcześniej omówione, w tym miejscu zajmiemy się studium kursorycznym.

Studium kursoryczne jest podstawowym rodzajem studium biblijnego, stanowi fundament, na którym winna opierać się lektura Pisma Świętego ${ }^{175}$. Polega na czytaniu całego Pisma Świętego, bez opuszczeń, księga po księdze, wszystkie księgi biblijne zarówno z Nowego, jak i ze Starego Testamentu, aby w ciągu roku odczytać słowo Boże w całości ${ }^{176}$.

Uczeń może podjąć studium kursoryczne według trzech wyznaczników: według miejsca, według liturgii i według rodzaju. Czytanie według miejsca polega na tym, że poszczególne księgi są czytane według ich kolejności występowania w Piśmie Świętym. Należy zacząć wówczas od Księgi Rodzaju w Starym Testamencie, a skończyć na Apokalipsie w Nowym Testamencie. Na przykład z najważniejszymi tekstami o królu Dawidzie uczeń zapozna się, po kolei czytając księgi: Pierwszą i Drugą Księgę Samuela, Pierwszą i Drugą Księgę Królewską oraz Pierwszą i Drugą Księgę Kronik, które występują w kanonie po kolei.

Drugim sposobem kursorycznej lektury biblijnej jest czytanie według liturgii. Polega ono na tym, że kolejność lektury jest dobrana według kolejności czytań w ciągu roku liturgicznego ${ }^{177}$. Studium liturgiczne oparte na czytaniach przeznaczonych do liturgii pozwala w sposób systematyczny rozważać kolejne perykopy ewangeliczne i inne księgi biblijne ${ }^{178}$. W ten

174 Zob. na ten temat: B. Stypułkowska, Wdrażanie uczniów do samokształcenia $w$ ramach szkolnej katechezy biblijnej, [w:] Dydaktyka w służbie katechezy, red. S. Dziekoński, Kraków 2002, s. 279-316; B. Stypułkowska, Wdrażanie uczniów do studium biblijnego w ramach katechezy szkolnej, „Sosnowieckie Studia Teologiczne” 6 (2003), s. 243-258.

175 L. Bouyer, Wprowadzenie do życia duchowego, dz. cyt., s. 39.

176 L. Bouyer, Wprowadzenie do życia duchowego, dz. cyt., s. 39.

177 Czytania przeznaczone do czytania podczas liturgii mszy świętej w dni powszednie mają charakter studium kursorycznego. W studium według liturgii należy kierować się zasadą, że słowo, które Kościół wyznaczył do przeczytania w czasie liturgii, jest tym właśnie słowem, które sam Bóg do nas kieruje na dany dzień czy okres.

178 Należy jednak pamiętać, że ograniczając studium biblijne tylko do tekstów przeznaczonych do czytania w czasie liturgii, uczeń pozna Biblię tylko fragmentarycznie. Jest wie- 
sposób uczeń również zapozna się z fragmentami pochwały ojców z Mądrości Syracha oraz fragmentami z 11 rozdziału Listu do Hebrajczyków.

Trzecim sposobem lektury kursorycznej jest czytanie według rodzaju ksiąg. Polega ono na czytaniu blokowym według rodzajów, np. najpierw wszystkie, następnie księgi historyczne, księgi prorockie i dydaktyczne. Uwzględniając żydowski charakter Starego Testamentu, można Stary Testament przeczytać z podziałem na Prawo, Proroków i Pisma.

Czytając w sposób kursoryczny Pismo Święte, uczeń dotrze do fragmentów przedstawiających postaci biblijne będące przykładami ludzi wiary i modlitwy. Można jedynie ukierunkować ucznia na to, by na tę tematykę zwrócił baczną uwagę.

\section{Wnioski końcowe}

Zapoznawanie uczniów z historią biblijną należy do zadań katechezy biblijnej realizowanej w trakcie nauczania religii w szkole oraz katechezy parafialnej. Historię biblijną można poznawać dzięki zaznajamianiu się z osobami reprezentatywnymi dla poszczególnych epok. Księgi biblijne podają wykazy osób będących wzorem wiary i modlitwy. We wskazaniach katechetycznych sugeruje się również przedstawienie w trakcie nauczania konkretnych osób. Wykazy biblijne podają szerszy zasób wzorców, co może stanowić wskazówkę dla katechety pragnącego wzbogacić program katechetyczny nauki religii w szkole. W odniesieniu do katechezy parafialnej, przy braku ogólnopolskich programów, katecheta może swobodnie wykorzystywać sugestie ksiąg biblijnych, uzupełniając wiedzę szkolną uczniów.

le teksów, które nie pojawiają się w liturgii, a znajdują się w Piśmie Świętym. Poza tym, poznając poszczególne perykopy biblijne, można patrzeć na nie jako na oddzielne fragmenty, nie domyślając się często ich kontekstu bliższego czy dalszego. Dlatego też studium liturgiczne należy uzupełniać o lekturę ciągłą wszystkich ksiąg biblijnych. 


\section{Summary}

\section{Biblical Examples of the People of Faith and Prayer in Catechetical Application}

Religious education should provide pupils with examples of the life of faith. Such examples can be found, first of all, in the Bible. Both in the Old and in the New Testament, we can read about people who met God and this fact influenced all their life. The biblical canon provide us with distinct catalogues of people to whom the God's Wisdom revealed itself and who are the examples of the life of faith. Two lists can be found in the Old Testament: one in the Book of Wisdom, verses 10,11-11, 3, second in the Wisdom of Sirach, in the so-called "Praise of the Ancestors", verses $44,1-50,21$. The third series occurs in the New Testament, written by the author of the Letter to the Hebrews in Chapter 11.

The present paper begins with the introduction of the catalogues of persons given by biblical authors as the examples of faith and prayer. Then follows the analysis of both the Core Curriculum of Catechesis of the Catholic Church in Poland and the Program of Roman Catholic religious education for kindergartens and schools with respect to this matter. The paper is concluded with suggestions for both the religious classes in public schools and the parish catechesis.

Keywords: religious classes, parish catechesis, adult catechesis, catechesis of children and adolescents, Core Curriculum, program of religion teaching, people of faith

\section{Biblijne przykłady ludzi wiary i modlitwy w zastosowaniu katechetycznym}

Nauczanie religii powinno dostarczyć uczniom przykładów życia wiary. Takie przykłady znajdziemy najpierw w Piśmie Świętym. Zarówno w Starym, jak i w Nowym Testamencie możemy przeczytać o osobach, które spotkały Boga, co wpłynęło na całe ich życie. W kanonie biblijnym mamy wyraźne wykazy ludzi, wobec których objawiła się Mądrość, będących przykładem życia wiary. Dwa spisy znajdują się w Starym Testamencie: jeden w Księdze Mądrości w wersetach 10,1-11, 3, drugi w Mądrości Syracha w tzw. pochwale ojców w wersetach 44,1-50, 21. Trzeci spis - w Nowym Testamencie - zamieścił autor Listu do Hebrajczyków w 11 rozdziale.

W niniejszym artykule najpierw zostały przedstawione wykazy osób, które autorzy biblijni podająjako przykłady wiary i modlitwy. Następnie została dokonana analiza Podstawy programowej katechezy Kościoła Katolickiego w Polsce i Programu nauczania religii rzymskokatolickiej w przedszkolach i szkołach pod tym kątem. $\mathrm{Na}$ końcu zostały podane propozycje dla lekcji religii w szkole i katechezy parafialnej.

Słowa kluczowe: lekcja religii, katecheza w parafii, katecheza dorosłych, katecheza dzieci i młodzieży, podstawa programowa, program nauczania religii, ludzie wiary 


\section{Bibliografia}

II Polski Synod Plenarny (1991-1999). Liturgia Kościoła po Soborze Watykańskim II, Poznań 2001, s. 189-216.

Biblia Jerozolimska, Poznań 2006.

Bouyer L., Wprowadzenie do życia duchowego. Zarys teologii ascetycznej i mistycznej, przeł. L. Rutowska, Warszawa 1982.

Encyklopedia biblijna, red. P. J. Achtemeier, Warszawa 1999.

Komisja Wychowania Katolickiego Konferencji Episkopatu Polski, Program nauczania religii rzymskokatolickiej w przedszkolach i szkołach, Kraków 2010.

Konferencja Episkopatu Polski, Dyrektorium duszpasterstwa służby liturgicznej, Warszawa 2009.

Konferencja Episkopatu Polski, Dyrektorium katechetyczne Kościoła katolickiego w Polsce, Kraków 2001.

Konferencja Episkopatu Polski, Podstawa programowa katechezy Kościoła Katolickiego w Polsce, Kraków 2010.

Kongregacja ds. Duchowieństwa, Dyrektorium ogólne o katechizacji, Poznań 1998.

Läpple A., Od egzegezy do katechezy. Nowy Testament, przeł. B. Białecki, Warszawa 1986.

Nowak W., Katecheza dorosłych i liturgia, [w:] Katecheza dorosłych w teorii i praktyce. Impulsy - wyzwania - perspektywy, red. C. Rogowski, Lublin-Olsztyn 2001, s. 137-157.

Pismo Święte Starego i Nowego Testamentu. Najnowszy przekład z języków oryginalnych z komentarzem. Opracował Zespół Biblistów Polskich z inicjatywy Towarzystwa Świętego Pawła, Częstochowa 2008.

Pismo Święte Starego i Nowego Testamentu w przekładzie z języków oryginalnych. List do Hebrajczyków, tłum., wstęp i komentarz ks. A. Paciorek, Lublin 1998.

Pismo Święte Starego i Nowego Testamentu w przekładzie z języków oryginalnych. Opracował zespót biblistów polskich z inicjatywy Benedyktynów Tynieckich, wyd. 5, Poznań 2000.

Pazera W., Pochwała ojców w Księdze Jezusa Syracha, „Częstochowskie Studia Teologiczne" 14 (1986), s. 271.

Pikor W., Hermeneutyka biblijna w katechezie. Interpretacja Pisma Świętego w świetle polskich dokumentów katechetycznych, „Katecheta” 51 (2007) nr 5, s. 3-11.

Poniży B., Księga Mądrości. Wstęp - przekład z oryginału - komentarz, Częstochowa 2012.

Poniży B., Sapiencjalne przejście od „przymierza” do „przyjaźni z Bogiem”, „Verbum Vitae" 4 (2003), s. 108-109.

Poniży B., Sprawiedliwy cierpiący. Echa Księgi Mądrości w ewangeliach synoptycznych, „Poznańskie Studia Teologiczne” 5 (1984), s. 106.

Potocki S., Księgi mądrościowe, [w:] Wstęp do Starego Testamentu, red. S. Łach, Poznań-Warszawa 1973, s. 631-751.

Potocki S., Rady mądrości. Przewodnik po mądrościowej literaturze Starego Testamentu, Lublin 1993.

Stypułkowska B., Wdrażanie uczniów do samokształcenia w ramach szkolnej katechezy biblijnej, [w:] Dydaktyka w stużbie katechezy, red. S. Dziekoński, Kraków 2002, s. 279-316. 
Stypułkowska B., Wdrażanie uczniów do studium biblijnego w ramach katechezy szkolnej, „Sosnowieckie Studia Teologiczne” 6: Chrześcijanin we współczesnym świecie (2003), s. 243-258.

Synowiec J. S., Gatunki literackie w Starym Testamencie, Kraków 2003.

Synowiec J. S., Mędrcy Izraela, ich pisma i nauka, Kraków 1997.

Tronina A., Do Hebrajczyków. Stowo zachęty na dni ostatnie, Częstochowa 1998. 
